\title{
Purification and genomic analysis of baculovirus associated with white spot syndrome (WSBV) of Penaeus monodon
}

\author{
Chung-Hsiung Wang ${ }^{1}$, Chu-Fang Lo ${ }^{2, *}$, Jiann-Horng Leu ${ }^{3}$, Chih-Ming Chou ${ }^{2}$, Pei-Yan Yeh ${ }^{2}$ \\ Hsin-Yiu Chou ${ }^{4}$, Min-Chen Tung ${ }^{5}$, Chen-Fang Chang ${ }^{6}$, Mao-Sen Su ${ }^{6}$, Guang-Hsiung Kou ${ }^{2}$ \\ ${ }^{1}$ Department of Plant Pathology and Entomology, ${ }^{2}$ Department of Zoology, National Taiwan University, Taipei, Taiwan, ROC \\ ${ }^{3}$ Institute of Biological Chemistry, Academic Sinica, Taipei, Taiwan, ROC \\ ${ }^{+}$Department of Aquaculture, National Taiwan Ocean University, Keelung, Taiwan, ROC \\ ${ }^{5}$ Department of Veterinary Medicine, National Ping Tung Polytechnic Institute, Ping Tung, Taiwan, ROC \\ ${ }^{6}$ Tung Kang Marine Laboratory, Taiwan Fisheries Research Institute, Tung Kang, Ping Tung, Taiwan, RoC
}

\begin{abstract}
The causative viral agent was purified from diseased shrimp Penaeus monodon with white spot syndrome. Negatively stained preparations show that the virus is pleiomorphic. It is fusiform or rod-shaped. In negatively stained preparations, the virion measures 70 to $150 \mathrm{~nm}$ at its broadest point and is 250 to $380 \mathrm{~nm}$ long. In some virions, a tail-like projection extends from one end. The capsid is apparently composed of rings of subunits in a stacked series. The rings are aligned perpendicular to the longitudinal axis of the capsid. The genome of the virus is a double-stranded DNA molecule which produces at least 22 Hind III fragments. The full length of the DNA is estimated to be longer than $150 \mathrm{kbp}$. Based on the morphological characteristics and genomic structures of the virus, we confirm that white spot syndrome associated virus (WSSV) is a member of genus NOB (Non-Occluded Baculovirus) of the subfamily Nudibaculovirinae of Baculoviridae, name the present isolate PmNOBIIl, and propose the use of WSBV (Baculovirus associated with White Spot syndrome) to indicate PmNOBIII related agents
\end{abstract}

KEY WORDS: PmNOBIII - WSBV - Baculovirus - Penaeus monodon. White spot syndrome

Recently, disease outbreaks have caused mass mortality among cultured penaeid shrimps in Asian countries. Moribund shrimp exhibited red coloration or discoloration and white spots on the body. A nonoccluded bacilliform virus is considered to be the causative agent of the disease (Inouye et al. 1994, Momoyama et al. 1994, Nakano et al. 1994, Takahashi et al. 1994, Chou et al. 1995, this issue). In this paper, we report our further studies on WSSV (white spot syndrome associated virus) isolated from Penaeus monodon in an attempt to define its taxonomic position.

- Addressee for correspondence.

E-mail: gracelow@ccms.ntu.edu.tw
Materials and methods. Samples of moribund penaeid shrimp Penaeus monodon (average weight $30 \mathrm{~g})$ were collected from shrimp farms located in southern Taiwan in November 1994. The samples were examined by gross anatomy and light and electron microscope for confirmation of the disease using the method described in Chou et al. (1995)

The purification of the virions of WSSV from experimental shrimp was carried out as follows. Experimental shrimp were first rinsed with cold $1 \times$ TE buffer (10 $\mathrm{mM}$ Tris- $\mathrm{HCl}, 1 \mathrm{mM}$ EDTA, pH 7.6). The exoskeleton with underlying epidermis taken from 1 to 5 live or frozen shrimp was extracted with $20 \mathrm{ml}$ cold extraction buffer $(20 \mathrm{mM}$ HEPES, $0.4 \mathrm{~N} \mathrm{NaCl}, 1 \mathrm{mM}$ EDTA, 1 mM EGTA, $1 \mathrm{mM}$ DTT, $2.5 \mathrm{mM}$ phenylmethylsulfonyl fluoride, $1 \mu \mathrm{g} \mathrm{ml^{-1 }}$ leupeptin, $1.6 \mu \mathrm{g}$ $\mathrm{ml}^{-1}$ pepstatin, $2 \mu \mathrm{g} \mathrm{ml}^{-1}$ aprotinin, $1 \mu \mathrm{g} \mathrm{ml}^{-1}$ bestatin), then purified by centrifugation on a linear 35 to $65 \%$ (W/W) sucrose gradient at $74700 \times g$ (Hitachi SRP $28 \mathrm{SA}$ rotor at $24000 \mathrm{rpm}$ ) for $60 \mathrm{~min}$. The visible viral band in the middle of the gradient was removed and pelleted by centrifugation at $74700 \times g$ at $4^{\circ} \mathrm{C}$ for $30 \mathrm{~min}$. The pellet was washed twice with cold $1 \times \mathrm{TE}$ buffer, resuspended with 300 to $500 \mu$ cold $1 \times \mathrm{TE}$ buffer depending on the size of the pellet, and immediately used for viral DNA extraction. A small volume of purified viral suspension was negatively stained with $2 \%$ phosphotungstic acid (PTA) at $\mathrm{pH} 7$ for the ultrastructural studies of the virions.

The extraction of viral genomic DNA from gradient purified virions was performed by proteinase $\mathrm{K}$ and $\mathrm{N}$-cetyl N,N,N-trimethylammonium bromide (CTAB) treatments followed by phenol-chloroform extraction and ethanol precipitation (Wilson 1994). The estimation 

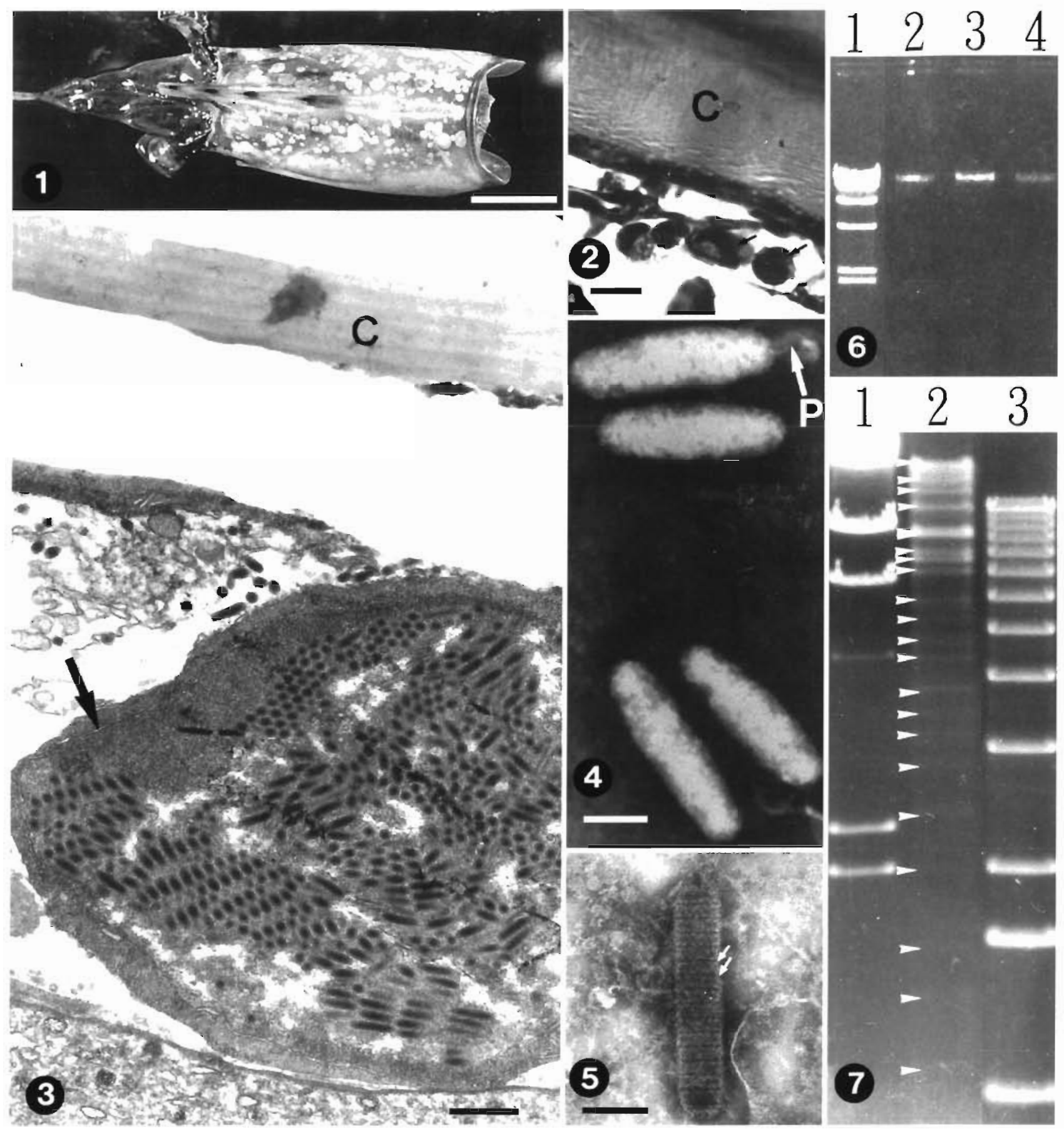

Figs 1 to 7. Penaeus monodon with white spot syndrome. Fig. 1. Photograph of carapace removed from $P$. monodon showing white spots ranging from barely visible to $3 \mathrm{~mm}$ in diameter. Scale bar $=1 \mathrm{~cm}$. Fig. 2 . Light micrograph of cuticular epidermis under the cephalothorax exoskeleton (C) showing basophilic inclusions in hypertrophied nuclei of degenerated cells (arrows). Scale bar = $10 \mu \mathrm{m}$. Fig. 3. Transmission electron micrograph of ultrathin section of infected tissue from beneath the cephalothoracic exoskeletal cuticle (C) showing viral particles in the necrotic area and in a hypertrophied nucleus (arrow). Scale bar $=0.5 \mu \mathrm{m}$. Fig. 4 . Transmission electron micrograph of negatively stained purlied virions showing a tall-like projection (P) extending from one end of the virus. Scale bar $=0.1 \mu \mathrm{m}$. Fig. 5. Transmission electron micrograph of negatively stained non-enveloped nucleocapsid showing the crossstriations on the capsid formed by the ring subunits (arrows). The rings are aligned perpendicular to the longitudinal axis of the capsid. Scale bar $=0.1 \mu \mathrm{m}$. Fig. 6. Ethidium bromide-stained agarose gel of PmNOBIII DNA extracted from purified virions. A single molecule of DNA is observed in the gel. Lane 1: $\lambda$ phage DNA Hind II fragment marker. Lanes 2 to 4: extracted PmNOBIIl DNA from each of 3 respective preparations. Fig. 7. Ethidium bromide-stained agarose gel of PmNOBIII DNA digested with Hind III restriction endonuclease. At least 22 DNA fragments (arrows) can be identified in this gel. Lane 1: $\lambda$ phage DNA Hind II fragment marker. Lane 2: PmNOB III DNA Hind III restriction endonuclease fragments. Lane 3: $1 \mathrm{~kb}$ DNA ladder 
of the viral genome size was done by restriction endonuclease analysis. Viral DNA was digested with Hind III restriction endonuclease (Boehringer Mannheim Company, Mannheim, Germany). Restriction fragments were separated by electrophoresis in $0.8 \%$ agarose gel $(9 \times 12 \mathrm{~cm})$, with Tris-acetate buffer $(0.04 \mathrm{M}$ Tris-acetate, $0.1 \mathrm{mM}$ EDTA, pH 8.0) containing $0.5 \mu \mathrm{g} \mathrm{m} \mathrm{m}^{-1}$ ethidium bromide. The 1 kilobase $(\mathrm{kb})$ DNA ladder and lambda phage Hind III fragment marker (Life Technologies, Inc.) were used as the DNA size standard on the gel.

Results and discussion. The main clinical signs of the disease in Penaeus monodon were the white spots on the exoskeleton (Fig. 1). The white spots were particularly obvious on carapaces removed from diseased shrimp, and were readily observed even on carapaces from lightly infected specimens. Histopathological study demonstrated that the epidermis of the diseased shrimp was attacked by a viral agent as was evidenced by the presence in this tissue of degenerated cells characterized by hypertrophied nuclei with inclusions (Fig. 2). Ultrathin sections of the underlying epidermis of the cuticle from shrimp with white spot syndrome viewed under the electron microscope revealed numerous non-occluded baculo-like viral particles in the necrotic areas. Hypertrophied nuclei filled with virions were also readily seen (Fig. 3 ). The virion was fusiform or rod-shaped with bluntly rounded ends. In negatively stained preparations, the virion was 70 to $150 \mathrm{~nm}$ at its broadest point, and was 250 to $380 \mathrm{~nm}$ long, $10 \%$ larger than is usually seen in ultrathin sections. In some virions, a tail-like projection extending from one end was observed (Fig. 4). The nonenveloped nucleocapsids were normally 58 to $67 \mathrm{~nm}$ in diameter and 330 to $350 \mathrm{~nm}$ long. The capsid components formed parallel cross-striations (Fig. 5). Thus, the capsid seemed to be composed of rings of subunits in a stacked series. The thickness of the rings was very constant, usually being $20 \mathrm{~nm}$. The rings were perpendicular to the longitudinal axis of the capsid. In terms of virus morphology, WSSV resembles SEMBV (systemic ectodermal and mesodermal baculovirus) and differs from BMN (baculoviral mid-gut gland necrosis virus) and PmSNPV ( $P$. monodon single nucleocapsid nuclear polyhedrosis virus = MBV) (Sano et al. 1984, Mari et al. 1993, Wongteerasupaya et al. 1995). However, the main clinical sign of white spot caused by WSSV was not described in the SEMBV infected shrimp. To date, it is difficult to guess the relation between WSSV and SEMBV.

A single DNA molecule was extracted from purified virions of WSSV (Fig. 6). The genomic DNA of WSSV digested with Hind III restriction endonuclease produced at least 22 fragments in agarose gel (Fig. 7) with the approximate sizes $19.4,16.9,14.9,12.5,10.0,9.6$, $8.4,8.0,7.3,6.1,5.5,4.8,4.3,3.9,3.6,3.3,3.0,2.5,2.0$,
1.6. 1.4, and $1.1 \mathrm{kbp}$. If they existed, any fragments smaller than $1 \mathrm{kbp}$ would have run over the gel. The length of WSSV DNA was estimated to be longer than $150 \mathrm{kbp}$. which falls within the size range of 90 to $230 \mathrm{kbp}$ found in insect baculoviruses (Francki et al. 1991).

Based on its morphological characteristics and genomic structure, WSSV is classified as the genus Non-Occluded Baculovirus (NOB) of the subfamily Nudibaculovirinae of Baculoviridae (Francki et al. 1991), and the isolate was named PmNOBIII as the third non-occluded baculovirus reported for Penaeus monodon (Lightner 1993, Wongteerasupaya et al. 1995). We also propose that WSBV (baculovirus associated with white spot syndrome) be used to indicate PmNOBIII related agents.

Acknowledgements. This work was supported by the Council of Agriculture under Grant No. 83 AST-1.1-FAD-61(65-2) and the National Science Council under Grant No. NSC 84-2321B-002-095B04, ROC.

\section{LITERATURE CITED}

Chou HY, Huang CY, Wang CH, Chiang HC, Lo CF (1995) Pathogencity of a baculovirus infection causing white spot syndrome in cultured penaeid shrimp in Taiwan. Dis aquat Org 23:165-173

Francki RIB, Fauquet CM, Knudson DL, Brown F (1991) Classification and nomenclature of viruses. Arch Virol. suppl 2:1-450

Inouye K, Miwa S, Oseko N, Nakano H, Kimura T (1994) Mass mortalities of cultured kuruma shrimp, Penaeus japonicus, in Japan in 1993: electron microscopic evidence of the causative virus. Fish Pathol 29:149-158 (in Japanese)

Lightner DV (1993) Diseases of cultured penaeid shrimp. In: McVey JP (ed) CRC handbook of mariculture, 2nd edn, Vol 1. Crustacean aquaculture. CRC Press, Boca Raton, p 393-486

Mari J, Bonami JR, Paulos B, Lightner D (1993) Preliminary characterization and partial cloning of the genome of a baculovirus from Penaeus monodon (PmSNPV $=\mathrm{MBV})$. Dis aquat Org 16:207-215

Momoyama K, Hiraoka M, Nakano $H$, Koube $H$, Inouye $K$, Oseka N (1994) Mass mortalities of cultured kuruma shrimp, Penaeus japonicus, in Japan in 1993: histopathological study. Fish Pathol 29:141-148 (in Japanese)

Nakano H, Koube H, Umezaea S, Momoyama K, Hiraoka M, Inouye K, Oseko N (1994) Mass mortalities of cultured kuruma shrimp, Penaeus japonicus, in Japan in 1993: epizootiological survey and infection trials. Fish Pathol 29: 135-139 (in Japanese)

Sano T, Nishimura T, Fukuda HR, Hayashida T, Monoyama K (1984) Baculoviral mid-gut gland necrosis (BMN) of kuruma shrimp (Penaeus japonicus) larvae in Japanese intensive culture systems. Helgoländer Meeresunters 37 : $255-264$

Takahashi Y, Itami T, Kondo M, Maeda M, Fujii R, Tomonaga S, Supamattaya K, Boonyaratpalin S (1994) Electron microscopic evidence of bacilliform virus infection in Kuruma shrimp (Penaeus japonicus). Fish Pathol 29(2): 121-125

Wilson K (1994) Preparation of genomic DNA from bacteria. 
Miniprep of bacterial genomic DNA. In: Ausubel FM, Brent R, Kingston RE, Moore DD, Seidman JG, Smith JA, Struhl $\mathrm{K}$ (eds) Current protocols in molecular biology. Vol. 1. Greene Publishing Associates, Inc, and John Wiley \& Sons, Inc., New York, p 2.4.1-2.4.5

Wongteerasupaya C, Vickers JE, Sriurairatana S, Nash GL,

Responsible Subject Editor: J. E. Stewart, Dartmouth, Nova Scotia, Canada
Akarajamorn A, Boonsaeng V, Panyim S, Tassanakajon A, Withyachumnarnkul $B$, Flegel TW (1995) A nonoccluded, systemic baculovirus that occurs in cells of ectodermal and mesodermal origin and causes high mortality in the black tiger prawn Penaeus monodon. Dis aquat Org 21:69-77

Manuscript first received: March 13, 1995

Revised version accepted: June 28, 1995 